Zabytkoznawstwo i Konserwatorstwo XL, Toruń 2011

Marcin Dawidowicz

\title{
Program ideowy gotyckich malowideł ściennych dawnej sali zebrań bractwa kupieckiego pw. NMP przy ul. Żeglarskiej 5 w Toruniu
}

$\mathrm{W}$ śród wielu wybitnych zabytków gotyckiego malarstwa ściennego zachowanych na obszarze Torunia znajduje się wyjątkowy cykl malarski ufundowany przez zamożne bractwo kupieckie pod wezwaniem Najświętszej Marii Panny w jego najstarszej siedzibie przy ul. Żeglarskiej 5. Malowidło to datowane jest na podstawie analiz stylistyczno-porównawczych i informacji źródłowych na ostatnie dziesięciolecie XIV wieku. Stanowi ono ciekawy przykład adaptacji na potrzeby zamożnego mieszczaństwa popularnych na obszarze państwa zakonu krzyżackiego motywów ikonograficznych. Potwierdzona źródłowo informacja, iż fundatorami dekoracji malarskiej kamienicy było bractwo kupieckie daje bezprecedensową możliwość rekonstrukcji roli dekoracji malarskiej w programie funkcjonowania specyficznej organizacji społecznej - zamożnej konfraterni zawodowej stanowiącej elitę ówczesnego patrycjatu. Tym samym otwiera to pole interpretacji malowidel, jako dokumentu rodzenia się nowej duchowości i świadomości społecznej toruńskich mieszczan schyłku XIV wieku.

W niniejszym artykule chciałbym dokonać analizy ikonograficznej malowideł, starając się przede wszystkim odpowiedzieć na pytanie, jakich znaczeń nabierają typowe dla drugiej połowy XIV wieku motywy ikonograficzne przetransponowane na grunt świeckiej fundacji oraz jakie motywacje stały za wyborem określonych tematów. Chciałbym również pokazać malowidła jako przejaw specyficznej duchowości mieszczańskiej na tle ówczesnych stosunków między instytucjami kościelnymi a społecznością miejską oraz jako przykład rodzenia się odrębnej w ówczesnych warunkach samoświadomości społecznej legi- 
tymizowanej treściami religijnymi. Niezbędne dla zrozumienia genezy powstania dekoracji malarskiej świetlicy budynku przy ul. Żeglarskiej 5 wydaje się również skrótowe nakreślenie sytuacji miast i mieszczaństwa w drugiej połowie XIV wieku, ze szczególnym uwzględnieniem specyfiki organizacji, jaką było bractwo kupieckie Najświętszej Marii Panny. Ze względu na objętość niniejszego tekstu skrótowy, siłą rzeczy, opis malowideł ustąpić musi miejsca zagadnieniom interpretacyjnym.

Gotyckie malowidła ścienne wypełniające wnętrze sali zebrań dawnego domu bractwa kupieckiego pod wezwaniem Najświętszej Marii Panny przy ul. Żeglarskiej 5 znajdują się w pomieszczeniu tylnego traktu drugiej kondygnacji budynku. Malowidła usytuowane są na ścianach: południowej, wschodniej i zachodniej. Odkryte na początku lat 60. fragmenty stanowią część większego cyklu². W zachowanych fragmentach znajdują się 4 sceny z życia Marii oraz przedstawienie św. Jerzego walczącego ze smokiem. Przedstawienia tworzą obszerny fryz o wysokości około 2 metrów usytuowany około 2 metry ponad poziomem podłogi. Obiega on trzy ściany pomieszczenia z największymi ubytkami w partii ściany południowej ${ }^{2}$. Sceny na ścianie wschodniej ujęte są w malowane architektoniczne obramienia o zmiennym rytmie podziałów, pozostałe sceny ukazane zostały w przestrzeni otwartej. Poniżej strefy fryzu wypełnionego malowidłami figuralnymi usytuowany jest pas ornamentu szablonowego, który tworzy powtarzający się motyw kwiatu granatu, poniżej zaś malowane kotary. Układ dekoracji reprezentuje typ kompozycyjny charakterystyczny dla jednoprzestrzen-

1 Po raz pierwszy wzmiankuje je w literaturze M. Paździor, Toruń-Nowoodkryte czternastowieczne malowidła ścienne, „Ochrona Zabytków” 1963, t. XVI, nr 2, s. 71. Stan badań nad malowidłami zobacz: Malarstwo gotyckie w Polsce, red. A. S. Labuda i K. Secomska, t. II: Katalog zabytków, Warszawa 2004, s. 104-105.

2 Odkryte w 1962 roku malowidła po wstępnym zabezpieczeniu zostały zasłonięte płótnem, pracom konserwatorskim poddane zostały w latach 1981-1985. D. Krakowiecka-Górecka, „Toruń, Żeglarska 5. Gotycka polichromia ścienna. Dokumentacja konserwatorska”, mps, PKZ, Toruń 1985; Z. Brochwicz, J, Domasłowski, M. Górzyńska, E. Okuszko, J, Wiklendt, Materiały i techniki malarskie $w$ średniowiecznych malowidłach ściennych $w$ domu dawnego Bractwa Kupieckiego przy ulicy Żeglarskiej 5 w Toruniu, Toruń 1991. 
nych wnętrz pozbawionych architektonicznej artykulacji ${ }^{3}$. Począwszy od lewej strony, na fryzie figuralnym znajdują się następujące przedstawienia: na ścianie wschodniej - Koronacja Marii, dalej Zwiastowanie i Nawiedzenie, na ścianie południowej, przy południowo-wschodnim narożu pomieszczenia - Pokłon Trzech Króli, dalej zaś, na przestrzeni prawie połowy ściany aż do naroża pomieszczenia, fryz figuralny nie zachował się, zaś na ścianie zachodniej znajduje się Św. Jerzy walczący ze smokiem.

Cykl scen z życia Marii oparty jest na powszechnie występujących w owym czasie schematach ikonograficznych typowych dla drugiej połowy XIV wieku. Przedstawienia oparte na tematach maryjnych należą do kanonu sztuki chrześcijańskiej i cieszyły się ogromną popularnością w całej sztuce średniowiecza, a ich cykliczne przedstawienia pojawiły się na przełomie XII i XIII wieku, zaś największą popularność zyskały właśnie na przełomie XIV i XV wieku . Dużą popularnością cieszyły się również na ziemiach państwa krzyżackiego. Zastosowane w cyklu z Żeglarskiej schematy ikonograficzne oparte są na wzorach wypracowanych w kręgu luksemburskiej Pragi w drugiej połowie XIV wieku. Do Polski dotarły one za pośrednictwem Śląska (Małujowice, Strzegom, Opole) i u schyłku wieku rozprzestrzeniły się na obszarze Pomorza Wschodniego (Toruń, Lidzbark Warmiński, Orneta) ${ }^{5}$. Na uwagę zasługuje przedstawienie Zwiastowania, w którym na łonach matek Marii i Elżbiety ukazano w medalionach nienarodzone postaci Chrystusa i św. Jana Chrzciciela, jest to jedno z pierwszych tego typu przedstawień w tej części Europy i jedyne w Toruniu'.

Historia domu bractwa kupieckiego przy ulicy Żeglarskiej 5 i samego bractwa, a szczególnie jego początki, są niejasne i trudne do zrekonstruowania. W starszej literaturze doszukiwano się $\mathrm{w}$ domach

3 Por. A. Karłowska-Kamzowa, Uwagi o systemach dekoracji gotyckich malowidet ściennych $w$ Polsce, „Biuletyn Historii Sztuki” 1971, t. XXXIII, s. 23-31.

4 J. Seibert, Leksykon sztuki chrześcijańskiej, Kielce 2007, s. 191-194.

5 J. Domasłowski, A. Karłowska-Kamzowa, A. S. Labuda, Malarstwo gotyckie na Pomorzu Wschodnim, Warszawa-Poznań, s. 17-28.

6 Ibidem, s. 24, por. również: G. M. Lechner, Heimsuchung Marias, w: LCI II [1970], szp. 234; idem, Maria gravida. Zum Schwangerschaftsmotiv in der bildenden Kunst, München 1981, ibidem. 
kompanijnych i stowarzyszeniach pod wezwaniem św. Jerzego początków instytucji zwanych później Dworami Artusa, tym samym przypisując im cechy i właściwości, które ukonstytuowały się z biegiem czasu i dopiero wyewoluowały na gruncie stowarzyszeń kupieckich. Należy pamiętać o tym, iż najstarsze dwory (mające charakter siedzib zawodowych całej warstwy kupieckiej) różniły się od późniejszych, mających już znamiona siedziby ekskluzywnego stowarzyszenia patrycjuszowskiego, współrządzącego miastem i posiadającego zupełnie inny status społeczny ${ }^{7}$. Faktem opartym na tekstach źródłowych jest natomiast to, iż kamienicę przy ul. Żeglarskiej 5 wiązano z najstarszą konfraternią zawodową wielkich kupców-hurtowników, głównie sukienników, którzy zaczęli pojawiać się w Toruniu już w końcu XIII wieku. Jak zauważa Elżbieta Pilecka, „ta grupa osób miała przeszczepić tradycje turniejów arturiańskich na lokalny grunt i kultywować je w domu kompanijnym"8. Ważnym epizodem w historii bractwa mariackiego jest połączenie się organizacji z bractwem św. Jerzego w $1385 \mathrm{roku}^{9}$. Przypuszcza się, iż przez jakiś czas oba bractwa korzystały z budynku przy ulicy Żeglarskiej. Powyższymi faktami tłumaczy się pojawienie się w cyklu malowideł budynku na Żeglarskiej przedstawienia św. Jerzego walczącego ze smokiem. W nowej siedzibie bractwa przy Rynku znajdowało się również niezachowane malowidło ze św. Jerzym.

Wystrój średniowiecznego domu bractwa kupieckiego rekonstruować można tylko hipotetycznie, informacje na ten temat zachowane są bowiem fragmentarycznie. Jedynym zachowanym elementem średniowiecznego wystroju jest dekoracja malarska. Jeśli chodzi o sprzęty użytkowe, jak dowodzi Elżbieta Pilecka, w XIV wieku musiały to

7 E. Pilecka, Średniowieczne Dwory Artusa w Prusach. Świadectwo kształtowania się nowej świadomości mieszczańskiej, Toruń 2005, s. 17.

8 Ibidem, s. 313.

9 Istnieją informacje mówiące o tym, iż powstałe już w 1311 roku bractwo św. Jerzego, rezydujące od 1385 roku w budynku przy Starym Rynku, przyjęło pod swoje skrzydła bractwo mariackie, wiążąc to $z$ warunkiem sfinansowania przez nie sklepienia w nowej siedzibie przy rynku. R. Heuer, Die drei Artushöfe und der Junkerhof in Thorn, Thorn 1917, s. 3, za: E. Gąsiorowski, Późnogotyckie szczyty o półkolistych zwieńczeniach w kamienicach miast dawnych Prus Królewskich, w: Conservatio est aeterna creatio. Księga dedykowana prof. Janowi Tejchmanowi, Toruń 1999, s. 174. 
być ławy, stoły i skrzynie. Ławy były nie tylko meblami o charakterze użytkowym, ale także dzieliły wnętrze i gości na mniejsze jednostki zwane właśnie Ławami ${ }^{10}$. We wnętrzach musiały się też znajdować odpowiednie meble służące do wspólnej biesiady i przechowywania naczyń, bowiem spotkaniom bractw towarzyszyła czasem konsumpcja wina i piwa. Na ladach, stołach i w szafach wystawiano akwamanile, misy, pokale, srebrne dzbany, różnorodne dekoracje stołu, zarówno funkcjonalne, jak i o znaczeniu prestiżowym ${ }^{11}$. Trudno już dziś jednoznacznie wskazać rodowód tego typu wnętrz, jednak jest on pochodną kilku typów miejsc spotkań wspólnoty miejskiej - hali kupieckiej, ratusza, prywatnego domu kupca, a zwłaszcza tradycyjnego domu gildii zawodowej ${ }^{12}$. Domniemywać można, iż świetlica, w której znajdowały się freski, miała pierwotnie szerokość całej kamienicy, a dzisiejsze jej podziały są wtórne.

Zawarty we freskach program ikonograficzny jest silnie sprzężony z koncepcją funkcjonowania domu zebrań bractwa kupieckiego oraz z ideologią i tożsamością tejże organizacji. Immanentnie zawarte we freskach treści nabierają dodatkowych znaczeń w konfrontacji z miejscem, w którym zostały umieszczone. Sama lokalizacja fresku w przestrzeni kamienicy nie jest niczym wyjątkowym. Pomieszczenie tylnego traktu drugiego piętra, zwane świetlicą, miało bardzo często dekorację malarską. Na obszarze Torunia znajdują się liczne przykłady zachowanych gotyckich malowideł ściennych w analogicznej lokalizacji przestrzennej ${ }^{13}$. Zważywszy jednak na fakt, iż pojedyncze zabytki

10 Istnieją informacje, iż już w końcu XIV wieku i na początku XV członkowie bractwa św. Jerzego w Toruniu i Dworu Artusa w Gdańsku zasiadali przy oddzielnych stołach w swych Ławach, G. Grunau, Die St. Georgen-Brüderschaft zu Ebling, Marburg 1995, s. 14-15, zaś o podziale gości na określone Ławy wiadomo np. w przypadku Dworu w Elblągu (początek XIV wieku) i Toruniu (koniec XIV wieku), J. Heuer, Die drei Artushöfe und der Junkerhofe in Thorn, s. 2, informacje za: E. Pilecka, Średniowieczne Dwory Artusa w Prusach, s. 113.

11 Ibidem, s. 113-114.

12 Ibidem, s. 115.

13 Do najlepiej zachowanych i największych należy dekoracja kamienicy przy ul. Królowej Jadwigi 9 (skomplikowany układ scen religijnych), kompletny (choć w dużej mierze rekonstruowany) wystrój malarski posiada również świetlica przy ul. Szerokiej 22 (sceny dworskie, drollerie, ornament roślinny), zachowały się także po- 
malarstwa ściennego odnajdujemy niemal w całej przestrzeni gotyckich kamienic (wielkie sienie, pomieszczenia parteru tylnego traktu, nisze ścian, oficyny, przechody), uznać należy, iż dekoracja malarska była standardowym elementem wyposażenia wnętrza zamożnej kamienicy mieszczańskiej. Najstarsze zabytki malarstwa ściennego we wnętrzach świeckich pochodzą już z okresu około 1350 roku (ul. Żeglarska 17/19), a więc z czasów, kiedy malarstwo gotyckie dopiero zaczynało pojawiać się powszechnie na obszarze miasta ${ }^{14}$. Wydaje się więc, iż ozdabianie swoich domostw malowidłami ściennymi było zjawiskiem powszechnym i bardzo szybko stało się jedną z podstawowych form zaspokajania potrzeb estetycznych społeczności miejskiej ${ }^{15}$. Analizy stylistyczne pozwalają wysnuć tezę, iż warsztaty zatrudniane przy licznych realizacjach malarskich w świątyniach toruńskich wykonywały mniejsze zlecenia w zamożnych kamienicach mieszczańskich ${ }^{16}$. Pamiętać należy o tym, iż malowidła ścienne wychodziły również na zewnątrz kamienic, znajdując równie bogatą przestrzeń dla kreacji artystycznej na fasadach, blendach, malowanych fryzach.

$\mathrm{Na}$ czym mogła więc polegać oryginalność dekoracji malarskiej kamienicy będącej siedzibą zamożnej i elitarnej konfraterni zawodowej? Sama kamienica na tle ówczesnego budownictwa nie odznaczała się wyróżniającymi ją cechami, toteż prawdopodobnie dopiero

jedyncze motywy, fragmenty większych całości malowideł w pomieszczeniach o podobnym charakterze, zobacz: J. Domasłowski, Malowidła ścienne w toruńskich średniowiecznych wnętrzach mieszczańskich, "Rocznik Muzeum w Toruniu” 1982, t. VIII, s. $28-43$.

14 Malarstwo gotyckie w Polsce, t. II: Katalog zabytków, s. 104.

15 Liczba malowideł $\mathrm{z}$ tego okresu jest oczywiście niemożliwa do oszacowania, duża część domów mieszkalnych była jeszcze w XIV w. drewniana bądź szkieletowa. Niemniej jednak liczba zachowanych po dziś dzień zabytków dowodzi dużej skali aktywności artystycznej warstwy mieszczańskiej, zobacz: J. Domasłowski, Malowidła ścienne $w$ toruńskich średniowiecznych wnętrzach, s. 28-43.

16 Bardzo bliskie stylistycznie malowidłom domu bractwa są realizacje $\mathrm{z}$ kościoła franciszkańskiego datowane na ostatnie dziesięciolecie XIV wieku; Koronacja Marii z pierwszego przęsła kaplicy międzyszkarpowej nawy południowej oraz odkryte współcześnie malowidło z ostatniej kaplicy tejże nawy przedstawiające Droge krzyżowa i Modlitwe w Ogrójcu. Zobacz na temat Koronacji Marii: Malarstwo gotyckie $w$ Polsce, t. II, s. 103-104; informacje na temat malowideł z ostatniej kaplicy dotychczas niepublikowane. 
dekoracja malarska wnętrza, późniejsza niż repertuar form architektonicznych siedziby bractwa, dawała przestrzeń do manifestowania rodzącej się samoświadomości i aspiracji społecznych ${ }^{17}$. Już sam temat realizuje podstawową potrzebę artystycznej waloryzacji jego tożsamości. Wezwanie bractwa - Najświętszej Marii Panny - w najoczywistszy sposób wyjaśnia wybór tematu głównego cyklu fresków. Pojawienie się we wnętrzu domu przy Żeglarskiej malowidła przedstawiającego św. Jerzego związane było z połączeniem bractwa Najświętszej Marii Panny i bractwa św. Jerzego w roku $1385^{18}$. Zarówno kult Marii, jak i św. Jerzego były ówcześnie powszechne. Matka Boska jako patronka zakonu krzyżackiego i św. Jerzy jak patron stanu rycerskiego są motywami niemal obiegowymi w religijności państwa zakonu krzyżackiego, a jednocześnie, nie było na ziemiach państwa zakonnego rozwiniętego kultu poszczególnych świętych. Nieprzypadkowym wydaje się wobec tego fakt, iż mieszczańskie organizacje wybierają na swoich patronów świętych o najbardziej nobilitującej randze. Religijne wezwania bractw są znakiem rodzenia się nowej pobożności. Konfraternie były formą działalności społecznej, która w efekcie tworzyła świat mieszczańskich wierzeń i obyczajów. Choć dzięki takim praktykom wiara była coraz bardziej obecna w życiu mieszczan, jednocześnie dochodziło do

17 Choć sama kamienica przy Żeglarskiej 5 reprezentuje typowe rozwiązania architektoniczne, jej położenie dowodzi wyjątkowej rangi. Ulica Żeglarska była wówczas jedną z najważniejszych ulic w mieście, jest to jedna z najstarszych ulic Starego Miasta Torunia, zamknięta po dziś dzień Bramą Żeglarską i jako jedna z pierwszych w mieście posiadała zabudowę murowaną W średniowieczu przy ul. Żeglarskiej mieszkali najbogatsi kupcy-patrycjusze, zasiadający często we władzach miejskich (radzie i ławie). O randze ulicy zaplanowanej z wielkim rozmachem dowodzi jej szerokość: 19 m, podczas gdy inne toruńskie ulice nie przekraczały 12 m; za: M. Arszyński, „Kamienica przy ulicy Żeglarskiej 5 w Toruniu. Dokumentacja historyczna do prac konserwatorskich", PKZ, Toruń 1961 (mps w archiwum Wojewódzkiego Konserwatora Zabytków w Toruniu), s. 4; E. Gąsiorowski, Toruńska kamienica mieszczańska, „Zeszyty Naukowe UMK, Zabytkoznawstwo i Konserwatorstwo" 1966, t. I, z. 16, s. 76 i 80; K. Mikulski, Przestrzeń i społeczeństwo Torunia od końca XIV do początku XVIII wieku, Toruń 1999, s. 356.

18 Stylistyka malowidła jest bardziej progresywna niż pozostałe sceny cyklu, toteż powstało ono prawdopodobnie najpóźniej. Wyraźne wpływy mistrza z Trzeboni każą datować je bliżej schyłku XIV wieku. 
laicyzacji życia religijnego ${ }^{19}$. Za określonymi działaniami ze sfery religii kryła się jednak określona „polityka” i świadomość partykularnych celów. Wybór określonych motywów ikonograficznych miał w pewnym wymiarze znaczenie propagandowe. Św. Jerzy wyrażał np. aspiracje bogatych mieszczan, którzy starali się o status rycerski, zaś obecność sacrum w życiu codziennym miała bardzo konkretny, niemal „ekonomiczny" wymiar ${ }^{20}$. Wybór tematu jest więc nie tylko emblematem realizującym religijne wezwanie obu bractw. Skala i monumentalność realizacji w obrębie dekorowanego pomieszczenia, złożoność programu ikonograficznego oraz progresywność stylistyki malowideł dowodzą, iż malowidło kryje w sobie dużo więcej niż tylko znak bractwa.

Spróbujmy wobec tego spojrzeć $\mathrm{w}$ duchu powyższych ustaleń na wybór i wymowę poszczególnych tematów malowideł domu bractwa. Najważniejsza scena cyklu Koronacja Marii obarczona jest w tradycji sztuki państwa zakonu krzyżackiego pozareligijnym potencjałem znaczeń, który wykorzystywano niejednokrotnie w instytucjonalnych partykularyzmach. Scena ta bardzo często była eksploatowana w propagandzie władzy zakonu krzyżackiego. Potencjałem politycznym obciążone było przedstawienie Koronacji w Wielkim Refektarzu zamku w Malborku. Malowidło, poprzez wywyższenie patronki zakonu i organizacji kościelnej, umieszczone nad głównym wejściem, w największej sali dostępnej również dla świeckich gości, odnosiło się do samej instytucji zakonu jako zbrojnego ramienia Kościoła. Znajdujące się pierwotnie w tejże sali malowidła ze scenami rycerskimi podkreślały prawdopodobnie świecki aspekt Koronacji ${ }^{21}$. Równie „polityczną" wymowę ma bliskie stylistycznie malowidłom brackim przedstawienie Tronującej Marii z Chrystusem z kapitularza oraz Sąd Ostateczny

19 M. Bogucka, H. Samsonowicz, Dzieje miast i mieszczaństwa w Polsce przedrozbiorowej, Wrocław-Warszawa-Kraków, t. I, s. 239.

20 „Bóg był pojęciem bardzo konkretnym w życiu mieszczanina. Opłaty Jemu składane miały zapewnić pomyślność w życiu doczesnym i pozagrobowym, były formą sacrum commercium. Bractwa i stowarzyszenia religijne zajmowały się też organizowaniem tych transakcji”. Ibidem, s. 241.

21 J. Domasłowski, Uwagi o programach ideowych i systemach dekoracyjnych gotyckich malowideł ściennych $w$ budowlach świeckich na terenie Prus Krzyżackich i Królewskich, w: Sztuka pobrzeża Bałtyku. Materiały Sesji Stowarzyszenia Historyków Sztuki, Gdańsk, listopad 1976, Warszawa 1978, s. 155; tam informacja o istnieniu malowideł o tematyce rycerskiej, s. 155, za: B. Schmidt, Die Marienburg, Würzburg 1958, s. 62. 
z krużganków zamku biskupów warmińskich w Lidzbarku. Wymowa malowidła sankcjonowała doczesną władzę biskupów warmińskich jako panów feudalnych, ponadto był to element walki propagandowej w sporze z zakonem krzyżackim o niezawisłość w zakresie jurysdykcji duchowej i zwierzchnictwa nad Warmią. Umieszczenie tego typu sceny w reprezentacyjnym wnętrzu zamkowym miało istotną wymowę ideową. Wysnuwa się również przypuszczenie, iż malowidło mogło być zaprogramowane jako propagandowy element oddziaływania na poddanych feudalnych biskupa, nawoływanie do posłuszeństwa zarówno w sferze duchowej, jaki świeckiej ${ }^{22}$. Koronacja Marii znajduje się ponadto w najważniejszych świątyniach toruńskich (bazylika św. Janów, kościół franciszkański, kościół św. Jakuba), natomiast nie odnajdujemy ani jednego przykładu tego tematu w innych kamienicach mieszczańskich, poza kamienicą domu bractwa. Koronacja Marii, odzwierciedlająca triumf Kościoła, umieszczana często w okolicach głównego wejścia, świadomie ubierana w monarchiczny feudalny kostium, stawała się manifestacją władzy i potęgi nie tylko religijnej, ale przede wszystkim instytucjonalnej. Nie ma wątpliwości, iż zamożne i liczące się w mieście bractwo kupieckie Najświętszej Marii Panny musiało zdawać sobie sprawę z potencjału propagandowego tematu Koronacji. Umieszczenie w kamienicy na Żeglarskiej malowidła o tak nośnym znaczeniu dowodzić musiało wysokich aspiracji bractwa mariackiego i świadomości wszystkich pozytywnych i pozareligijnych konotacji, jakimi owa scena była obciążona. Okazuje się więc, że wybór tematu, jego lokalizacja, znaczenie ideowe bardzo silnie związane były z partykularnymi celami stawianymi sobie przez kupiecką organizację. Koronacja Marii jako triumf Kościoła była jednocześnie triumfem każdej instytucji (organizacji, grupy społecznej), która oddawała się jej patronatowi i opiece. Zaś cele i zadania, jakie sobie stawiała, legitymizowane były boskim wstawiennictwem Marii23.

22 Malarstwo gotyckie na Pomorzu Wschodnim, s. 28; J. Domasłowski, Malarstwo ścienne na Pomorzu Wschodnim, w: Malarstwo gotyckie w Polsce, s. 121; idem, Gotyckie malowidła ścienne na zamku biskupim w Lidzbarku Warmińskim, w: Średniowieczne zamki Polski Północnej. Wybór materiałów zsesji, Muzeum Zamkowe w Malborku, Malbork 1983, s. 89-99; Idem, Uwagi o programach ideowych i systemach dekoracyjnych, s. 156-157.

23 Por. D. Norman, Siena and the Virgin: Art and Politics in a Late Medieval City State, Nev Haven, London 1999. 
Czy również pozostałe sceny obciążone były podobną rolą? Niewątpliwie również pozareligijny potencjał treściowy miały sceny o charakterze dworsko-rycerskim, a więc Pokłon Trzech Króli i Walka św. Jerzego ze smokiem. Z powtórzeniem podobnych tematów mamy do czynienia w izbie sąsiadującej $\mathrm{z}$ refektarzem zamku w Malborku. W ramach dekoracji zamku zakonnego Walka św. Jerzego była symbolem walki z pogaństwem, zaś Pokłon nawiązywał do zadań misyjnych zakonu. W obu scenach religijna misja realizowana jest przez reprezentantów świata feudalnego, co nabiera oczywistej wymowy w kontekście rycerskiego charakteru zakonu ${ }^{24}$. Jakiego wymiaru nabiera jednak ta scena przetransponowana na grunt kamienicy mieszczańskiej? Nie można tu raczej mówić o gloryfikacji roli zakonu i wyższych warstw społecznych drabiny feudalnej poprzez adaptację bliskich im treści. Pod koniec wieku spory z zakonem nasilały się już nagminnie, a konflikty na tle ekonomicznym doprowadziły niebawem do zrzucenia $z$ siebie jarzma krzyżackiej dominacji ${ }^{25}$. Również warstwy feudalne były raczej konkurencją dla miasta niż jego społecznym zapleczem. Mamy więc do czynienia jedynie z transkrypcją etosu rycerskiego i ideałów wyżej stojącej w drabinie feudalnej warstwy społecznej. „Niewielka liczba dużych miast, obcość etniczna, wreszcie brak tradycji stanowych rozwiniętych na zachodzie Europy, stworzyły sytuację, w której przedstawiciele bogatych mieszczan widzieli dla siebie szansę w uzyskaniu bardzo atrakcyjnego statusu rycerstwa polskiego" ${ }^{26}$. Pamiętać należy również o tym, iż bractwo mariackie było zalążkiem rodzących się wówczas bractw arturiańskich przeszczepiających na grunt mieszczański ideały rycerskie. Zaryzykować można stwierdzenie, iż wybór pozostałych tematów łagodził ową niepokorną potrzebę manifestowania swojej wyższości i aspiracji społecznych. Jak powszechnie wiadomo, scena Nawiedzenia jest dla odmiany symbolem posłuszeństwa Marii i wypełnienia posłannictwa s. 155.

24 J. Domasłowski, Uwagi o programach ideowych i systemach dekoracyjnych,

25 J. Karwiński, Sprawy i spory pomiędzy Polakami a Zakonem Krzyżackim, t .III, Warszawa 1935, s. 75; J. Tandecki, Rozkwit toruńskiego ośrodka handlowego i produkcyjnego w latach 1350-1411, w: Historia Torunia, t. I: Wczasach średniowiecza (do roku 1454), red. M. Biskup, Toruń 1999, s. 212-214.

26 M. Bogucka, H. Samsonowicz, Dzieje miast i mieszczaństwa, s. 77. 
danego przez Boga. Zwiastowanie przypomina zaś o pokorze i posłuszeństwie względem patronki bractwa. Również i ten motyw znalazł redakcję o podobnej wymowie w dekoracji malarskiej zamku krzyżackiego w Malborku ${ }^{27}$.

Podkreślić należy jednak, iż choć koncepcja dekoracji malarskiej kamienicy ma w swojej wymowie ideowej wydźwięk „polityczny”, nie można uprościć znaczenia malowidła tylko do tej płaszczyzny. Nie ma wątpliwości, że fresk toruński wyrasta z potrzeb religijnych i w całej rozciągłości jest przesycony pierwiastkiem duchowym. Duchowa konstrukcja unaocznia się w wysokim poziomie koncepcji teologicznej cyklu. Pogłębienie wymowy malowideł nie tylko o uwspółcześniający ją monarchiczny i feudalny kostium, ale też o znaczące w tradycji Pisma Świętego rekwizyty (Ława Tron, otwarta Księga w scenie Zwiastowania, kwiat granatu, banderola z cytatem) czy też obciążony skomplikowanymi konotacjami religijnymi motyw nienarodzonych Dzieciątek na łonach matek św. Elżbiety i Marii, dowodzą, iż program ikonograficzny cyklu nie mógł być spontaniczną koncepcją wyłącznie środowiska kupieckiego. Motywy ikonograficzne nie są poza tym zaczerpnięte $z$ lokalnej tradycji religijnej, lecz wywodzą się z rozwiązań wypracowanych w rozwiniętych środowiskach artystycznych Europy ${ }^{28}$. Próbę odczytania wymowy malowideł jako znaku aspiracji kupieckiej tożsamości należałoby więc uzupełnić jeszcze o analizę religijnej genezy wariantów motywów ikonograficznych zacytowanych przez bractwo.

Jak starałem się udowodnić powyżej, za wyborem tematów kryła się określona polityka zamożnej konfraterni, niemniej jednak ich wymowa miała wymiar religijny i wyrastała z określonej duchowości. Zawarte we fresku motywy ikonograficzne oraz wątki mistyczne zwracają uwagę na

27 Por. J. Domasłowski, Uwagi o programach ideowych i systemach dekoracyjnych, s. 153.

28 Np. nagie Dzieciątko na kolanach Marii w scenie Pokłonu interpretowane jest jako hostia podczas Eucharystii i pojawia się w takiej redakcji jako jedno z pierwszych w Kaplicy Saskiej w katedrze św. Wita, a do Polski dociera za pośrednictwem Śląska (malowidła w Małujowicach), za: Z. Všetečková, Nástěnné malby v kostele Všech svatých v Malujowicích a jejich vztah $k$ malírství 14. století v echach, w: Ślask i Czechy. Wspólne drogi sztuki: materiały konferencji naukowej dedykowane Profesorowi Janowi Wrabecowi, red. M. Kapustka, A. Kozieł, P. Oszczanowski, Wrocław, 2007, s. 84. 
wpływ zakonu franciszkańskiego na program treściowy zespołu malowideł brackich. Motywy maryjne oraz Pokłon Trzech Króli są mocno zakorzenione w duchowości i dydaktyce religijnej zakonu franciszkanów, który odegrał ogromną rolę w duchowej formacji młodych komun miejskich. Koronacja Marii znajduje się przy głównym wejściu do kościoła franciszkańskiego od strony rynku, na skarpach poniżej monumentalnych figur odnajdujemy temat Pokłonu i Zwiastowania, powtarza je również poliptyk toruński. Monumentalne w skali kamienicy malowidła śmiało cytują dekoracje jednej z najważniejszych świątyń miasta, nadając im indywidualną wymowę i znaczenie. Przejęcie przez bractwo kupieckie Najświętszej Marii Panny rudymentarnego repertuaru religijnych środków oddziaływania wizualnego liczących się instytucji kościelnych dowodzi, iż ono również aspirowało do bycia liczącą się na arenie miasta instytucją o prestiżowym charakterze i dostrzegalnym już u schyłku XIV wieku znaczeniu. Rozbudzone aspiracje artystyczne i działalność ewangelizacyjna w społeczności gminy miejskiej stwarzały podatny grunt dla „wychodzenia” sztuki franciszkańskiej poza obręb murów ich świątyni. Jak dowodzi Anna Błażejewska, powołując się na Marię Michnowską i Janinę Kruszelnicką, franciszkanie - autorzy koncepcji ołtarza głównego i lektoryjnego oraz witraży prezbiterium, świadomi siły oddziaływania środków wizualnych - musieli posiadać program duszpasterski, którym zamierzali objąć społeczność całego miasta głównie za pomocą właśnie środków wizualnych ${ }^{29}$.

Ważną kwestią w tym kontekście jest fakt, na który zwraca uwagę $\mathrm{w}$ podsumowaniu swojego artykułu na temat związków pobożności mieszczańskiej i duchowości franciszkańskiej Anna Błażejewska, iż choć samoświadomość społeczna mieszczaństwa była w końcu XIV wie-

29 A. Błażejewska, Czternastowieczny wystrój kościoła Mariackiego w Toruniu: duchowość franciszkańska a pobożność miejska, w: Dzieje i skarby kościoŁa Mariackiego w Toruniu: materiały z konferencji przygotowanej przez Torunski Oddział Stowarzyszenia Historyków Sztuki przy wspótpr. Instytutu Zabytkoznawstwa i Konserwatorstwa Uniwersytetu Mikołaja Kopernika (Toruń 14-16 kwietnia 2005), red. K. Kluczwajd, Toruń 2005, s. 59; J. Kruszelnicka, Dawny ołtarz Pięknej Madonny Toruńskiej, „Teka Komisji Historii Sztuki” 1968, t. IV, s. 5-85; M. Michnowska, Ze studiów nad XVI-wiecznym poliptykiem toruńskim, „Teka Komisji Historii Sztuki” 1961, nr 2, s. 119-207. 
ku już dość duża, w sferze artystycznej pozostawało ono wciąż odbiorcą wzorów artystycznych. Pomimo że mieszczanie finansowali większość dzieł, a ponadto mniejsze przedstawienia w wystroju np. kościoła franciszkańskiego zdają się wywodzić z potrzeb gminy miejskiej, większość realizacji „daje się genetycznie wyprowadzić z religijności franciszkańskiej bądź krzyżackiej”30. Franciszkanie byli fundatorami dzieł o najwyższym poziomie w obrębie ówczesnego środowiska artystycznego, ich oryginalność musiała wywierać ogromny wpływ na ówczesną sztukę Torunia. Podkreśla się np., iż koncepcja ikonograficzna poliptyku toruńskiego jest niepowtarzalna i jednorazowa nie tylko w skali regionu, ale też Europy ${ }^{31}$. Zaś jego autora (autorów bądź kierownika zespołu) uważa się za jedną z największych indywidualności wśród artystów drugiej połowy XIV wieku w Toruniu ${ }^{32}$. Kulturotwórcza rola zakonu w życiu mieszczan musiała być wobec tego niezaprzeczalna.

Liczne wątki treściowe każą odnosić freski domu bractwa do redakcji wyrosłych $\mathrm{z}$ ducha religijności franciszkańskiej. Nawiedzenie staje się samodzielną sceną dopiero po wprowadzeniu przez franciszkanów święta Nawiedzenia (1263 rok). Dopiero pod wpływem mistyki franciszkańskiej Nawiedzenie uznane zostało za jedną z radości Marii i stało się przez to ważnym epizodem z jej życia. Istotny wpływ na sposób ukazywania Pokłonu trzech króli miała XIV-wieczna myśl franciszkańska. W jej duchu podkreślano osobisty związek Dzieciątka z królami, np. poprzez całowanie bądź dotykanie nóżki, czasem rączki. Motyw Dzieciątka na łonach matek, pochodna motywu Maria Gravida, nacechowany bardzo mocno mistycyzmem, w środowisku religijnym Torunia najłatwiej daje się wywieść z mistycznych pism franciszkańskich i propagowanej przez nich specyficznej żarliwości religijnej. Tematy większości scen dekoracji domu bractwa odnajdujemy w dekoracji kościoła franciszkańskiego. Jak zauważa Anna Błażejewska, w kontekście sceny Pokłonu Trzech Króli znajdującej się w nawie południowej na szkarpie poniżej postaci św. Krzysztofa, przedstawienie to bliskie było my-

30 A. Błażejewska, Czternastowieczny wystrój kościoła Mariackiego w Toruniu, s. 85.

31 M. Michnowska, Ze studiów nad XVI-wiecznym poliptykiem toruńskim, s. 122.

32 A. Błażejewska, Czternastowieczny wystrój kościoła Mariackiego w Toruniu, s. 27. 
śli franciszkańskiej i specyfice ich zakonu, i nie może być traktowane jako spontaniczna koncepcja środowiska mieszczańskiego ${ }^{33}$. Również poliptyk toruński zawiera scenę Pokłonu, której schemat kompozycyjny i stylistykę zacytuje przedstawienie z Żeglarskiej. Wspomniana badaczka podkreśla również, że program monumentalnych malowideł nawy południowej kościoła franciszkańskiego operuje systemem znakowym, odchodząc od obowiązującej we franciszkańskim obrazowaniu i dydaktyce tendencji narracyjnej. Franciszkanie, świadomi swojej roli i celów w życiu religijnym mieszczan, posługiwali się określonym repertuarem środków wyrazu opartym w dużej mierze na oddziaływaniu znaku ${ }^{34}$. Malowidła domu bractwa kupieckiego nacechowane są żywiołem narracyjnym, jednak warstwa „fabularna” malowideł jest tylko kanwą, na której opiera się logika słowa - treści ukrytych nie w narracji, ale w symbolach, znaczeniach naddanych ponad przedstawioną na fresku historią. Można zaryzykować stwierdzenie, iż oba dzieła wyrastają z podobnej duchowości i zawierają pierwiastek dydaktyczny realizowany w podobnym duchu. Ze względu na wyrafinowany program ikonograficzny malowideł można postawić też tezę, iż za program ikonograficzny cyklu dekoracji z Żeglarskiej odpowiedzialny był wykształcony franciszkanin.

Wszystkie najważniejsze dzieła kościoła Mariackiego - malowidła na szkarpach i mniejsze przedstawienia poniżej nich oraz poliptyk toruński i witraże - wyrastają z inspiracji środowiska czeskiego drugiej połowy XIV wieku. Zakon franciszkanów odegrał ogromną rolę na obszarze całej Europy w procesie przeszczepiania rozwiązań nowej formacji stylowej, wydaje się również, iż na terenie Torunia zjawisko miało analogiczny przebieg. Potwierdza to bliskość stylistyczna dekoracji domu bractwa, nacechowanej wpływami malarstwa czeskiego względem malowideł świątyni franciszkańskiej z ostatnich dziesięcioleci wieku XIV.

33 Umieszczenie Pokłonu w obecności postaci św. Krzysztofa podkreślało prawdopodobnie rolę trzech magów jako patronów dobrej podroży. Temat wędrówki trzech mędrców ukazany na tle murów Betlejem obok sceny Zwiastowania przywołuje wydarzenia z Ziemi Świętej. Franciszkanie byli zakonem strzegącym miejsc świętych, organizowali pielgrzymki. Ibidem, s. 84 .

34 Ibidem, s. 84. 
Warta osobnego zbadania wydaje się kwestia genezy motywu nienarodzonych dzieciątek na łonach matek w scenie Nawiedzenia. Przedstawienie to jest wizualną reprezentacją i rozwinięciem popularnego już w XIII wieku motywu Maria gravida. Typ obrazowy Marii ciężarnej stanowi w sztuce średniowiecza przedmiot dojrzałej dewocyjnej ikonografii. Badacze doszukują się genezy tego motywu w kontekście rozwoju pobożności obrazowej rozwijającej się pod mecenatem cesarza Karola IV. Choć motyw ten występuje ówcześnie w całej niemal Europie, na przełomie XIV i XV wieku staje się niezwykle popularny na terenie luksemburskich Czech i Śląska, zaś w latach 1390-1420 doczekał się licznych realizacji zwłaszcza w rzeźbie ${ }^{35}$. W Nawiedzeniu cyklu brackiego Maria rozchyla płaszcz, ukazując przed Elżbietą postać Chrystusa na medalionie. Osłonięcie i tekstylne okrycie symbolu brzemienności wnosi w wymowę motywu Maria gravida pierwiastek świętej relikwii ${ }^{36}$. Warto podkreślić, iż geneza przedstawienia Marii z Dzieciątkiem na łonie bierze swój początek z rzeźby. W plastycznych wersjach tej formy przedstawienia figury św. Elżbiety i Marii mogą posiadać nawet małe, zamykane schowki, w których znajdują się figury dzieciątek ${ }^{37}$. Mamy więc we fresku brackim nie tyle innowację ikonograficzną, co malarskie rozwinięcie motywu o długiej tradycji obciążonego skomplikowanymi konotacjami z pogranicza teologii i żarliwości religijnej bliskiej substancjalnemu odczuwaniu świętości. Również w tym przypadku trudno przypuszczać, aby motyw ten pojawił się w dekoracji kamienicy jako

35 M. Kapustka, Obraz brzemiennej Marii i jego tekstylna metaforyka. O średniowiecznym typie Maria gravida na Śląsku i w Czechach, w: Śląsk i Czechy wspólne drogi sztuki, s. 99-112; tam również obszerna bibliografia tematu, por. A. Jagodzińska, Maria Dobrej Nadziei - styl i ikonografia rzeźby z terenu państwa zakonnego w Prusach, „Teka Komisji Historii Sztuki” 2005, t. X: Materiały sesji naukowej poświęconej pamięci profesora Gwidona Chmarzyńskiego w trzydziestą rocznicę śmierci, Toruń, 12-14 grudnia 2003, red. J. Poklewski, Toruń 2005.

36 Motyw ten znany jest i rozpowszechniony w sztuce w różnych wariantach, np. w nieco tylko późniejszych względem fresków brackich miniaturze w Godzinkach Boucicaut $\mathrm{z}$ lat 1405-1408, gdzie Maria delikatnym ruchem odsłania wydatny brzuch przed Elżbietą. Innym przykładem jest przedstawienie na ornacie z Rokycan z lat 1380-1390, w którym Maria rozchyla płaszcz, ukazując na łonie maleńką postać Dzieciątka, za: M. Kapustka, Obraz brzemiennej Marii.

37 J. Seibert, Leksykon sztuki chrześcijańskiej, s. 222. 
spontaniczna koncepcja zamożnych kupców, zaś jego mistyczna wymowa ponownie zwraca uwagę na wpływ zakonu franciszkańskiego.

Aby wyjaśnić w pełni genezę powstania malowideł brackich, należałoby teraz przenieść powyższe ustalenia na ówczesny kontekst historyczny i społeczny. W badaniach nad średniowieczną sztuką Torunia obserwuje się w ostatnim czasie tendencje do łączenia zagadnień natury artystycznej z przemianami społecznymi ${ }^{38}$. Korzystając z pewnych tropów badawczych rozwijanych w literaturze tematu, chciałbym włączyć się w powyższy nurt interpretacji zjawisk artystycznych i pokusić się o wykazanie związków, jakie zachodziły między przemianami społecznymi i kulturalnymi w XIV-wiecznym Toruniu, a przemianami w sztuce tego okresu. Specyfika bractwa kupieckiego, fundatora malowideł z Żeglarskiej 5, pozwala rozszerzyć ich kontekst interpretacyjny społecznie. Jak zauważa Ireneusz Czarciński „współczesna mediewistyka podejmuje coraz częściej badania nad korporacjonizmem w średniowieczu, widząc w nich jedną z możliwości odtworzenia struktury społecznej miast średniowiecznych"39, toteż obszerny już dziś stan badań na temat średniowiecznego korporacjonizmu pozwala $\mathrm{w}$ przypadku malowideł z Żeglarskiej posunąć się w interpretacji dalej niż w przypadku anonimowej fundacji dekoracji kamienicy mieszczańskiej.

Liczne podatki, związane z rozwojem handlu, nakładane na bogacącą się warstwę kupiecką dostarczały miastom środków niezbędnych do niezwykłej eksplozji budownictwa, która była bezpośrednim rezultatem i jednocześnie dowodem wolności i dobrobytu komun miejskich. Na terenie Torunia od drugiej połowy XIV wieku i w początkach wieku $\mathrm{XV}$ trwa okres rozkwitu gospodarczego, któremu w naturalny sposób towarzyszy intensywny rozwój budownictwa i działalności artystycznej. Wraz z rozwojem ekonomicznym Starego Miasta i upowszechnieniem

38 Np. E. Pilecka, Kościół p.w. św. Jana Chrzciciela i św. Jana Ewangelisty w Toruniu w okresie średniowiecza jako wizualizacja świadomości społecznej, w: Dzieje i skarby kościoła świętojańskiego w Toruniu: materiały z konferencji przygot. przez Toruński Oddział Stowarzyszenia Historyków Sztuki w X rocznicęustanowienia Diecezji Toruńskiej pod patronatem Biskupa Toruńskiego oraz Prezydenta Miasta Torunia (22-23 marca 2002), red. K. Kluczwajd, M. Woźniak, Toruń 2002.

39 I. Czarciński, Bractwa w wielkich miastach państwa krzyżackiego $w$ średniowieczu, Toruń 1993, s. 3. 
się świeckich form życia religijnego mieszczan, któremu towarzyszył wzrost zapotrzebowania na własne ośrodki kultu religijnego (ołtarze, kaplice), dochodzi w połowie XIV wieku do rozbudowy najważniejszych świątyń toruńskich. Gospodarczo miasto osiągnęło bezprecedensowy w ówczesnej skali poziom rozwoju i zamożności. Bogatych patrycjuszy stać było na zatrudnianie w swoich domach i przy własnych ołtarzach w kościołach prywatnych kapelanów. Liczne fundacje były manifestacją pozycji danego mieszczanina w społeczeństwie. Mówi się nawet o pewnej „ekonomii zbawienia” - rozważna fundacja kaplicy czy altarii mogła być doskonałą lokatą kapitału ${ }^{40}$. U schyłku wieku rozbudowano również kompleks budowli rynkowych na terenie Starego Miasta, zaś w latach 1385-1386 ukończono budowę Dworu Artusa, siedziby patrycjuszowskiego Bractwa św. Jerzego ${ }^{41}$.

Wszystkie te zjawiska rozwijają się jednak na tle specyficznych warunków egzystencjalnych. Na zachodzie Europy unaocznia się kryzys instytucji Kościoła, szaleje Czarna Śmierć wywołująca nastrój pesymizmu i schyłkowości. Niepokój egzystencjalny powoduje wzrost uczuć religijnych, zaś brak oparcia w instytucjach Kościoła - indywidualizację wiary. Pojawia się tzw. devotio moderna - nowa pobożność, oparta na mistycznej żarliwości religijnej, indywidualnych praktykach religijnych i kulcie Chrystusa. Choć wielka zaraza omija liczne obszary Europy Środkowowschodniej, zaś autorytet instytucji Kościoła jest na tym obszarze dużo silniejszy, konsekwencje $\mathrm{w}$ postaci przemian w duchowości i religijności docierają i do Torunia ${ }^{42}$. Niepokoje egzystencjalne towarzyszyły człowiekowi średniowiecza nawet w sprzyjających warunkach ekonomicznych. W 1351 roku pustoszy miasto wielki pożar. Ponadto gospodarcza sytuacja miasta średniowiecznego nie była stabilna. Handel natrafiał na poważne przeszkody naturalne i polityczne. Miastom stale zagrażali feudałowie (w tym przypadku zakon krzy-

40 P. Oliński, Mieszczanin w trosce o zbawienie, w: Eclesia et civitas. Kościót i życie religijne $w$ mieście średniowiecznym, Warszawa 2002, s. 348.

41 Historia Torunia, t. I: W czasach średniowiecza (do roku 1454), t. I, red. M. Biskup, Toruń 1999, s. 224.

42 Wielki cywilizacyjny kryzys, jakim była zaraza czarnej śmierci, spowodował np. rozwój ruchów religijnych o podłożu mistycznym, np. biczowników, którzy pojawiają się w drugiej połowie wieku także w Toruniu. 
żacki), którzy nie zrezygnowali całkowicie z prób utrzymania nad nim kontroli ${ }^{43}$. Konflikty społeczne w mieście stanowiły wciąż źródło niepokojów ${ }^{44}$. Wszystkie te czynniki wywołują szybki rozwój organizacji i zrzeszeń kupieckich, intensyfikują działalność Kościoła, który stara się kontrolować prywatne życie religijne mieszkańców poprzez nadzór nad organizacjami, w których uczestniczą ${ }^{45}$. Dopiero na takim tle obecność religijnego cyklu w dekoracji malarskiej domu zebrań bractwa kupieckiego wydaje się naturalna, zaś żarliwość religijna kupieckiego stowarzyszenia staje się nie tyle potrzebą duchową, co sytuacyjną koniecznością.

Jak wobec tego w program działalności bractwa kupieckiego NMP $\mathrm{w}$ Toruniu wpisuje się jego fundacja artystyczna z końca XIV wieku? Należy pamiętać o tym, iż moment powstania malowideł brackich dzieli od lokacji miasta in crudo vadere niespełna 150 lat. Od momentu, kiedy w nowym miejscu tworzy się niemal od podstaw społeczność, do schyłku XIV wieku dochodzi do żywych i dynamicznych zmian. W tym czasie wykształca się bogaty patrycjat. Zajmujący się handlem - kupcy i hurtownicy - mają wyższy status społeczny niż rzemieślnicy. To ci pierwsi zajmują urzędy i ważne funkcje w mieście. Organizują się niebawem w elitarne stowarzyszenia, do których dostęp mają tylko ludzie o podobnym statusie materialnym i wykonujący podobny zawód. Są to organizacje o charakterze religijnym, ale realizujące partykularne cele ekonomiczne i społeczne. Wciąż jednak cała ta struktura funkcjonuje w obrębie społeczeństwa stanowego (feudalnego). Choć, jak mawiało się w średniowieczu, „powietrze miasta czyni wolnym”, również w obrębie gminy miejskiej tworzą się wewnętrzne podziały. Przynależność do bractwa zapewniała określone miejsce w społeczności, najczęściej uznawane przez władze kościelne i państwowe, ale zwykle przekraczające

43 J. Karwasińska, Sprawy i spory pomiędzy Polakami a Zakonem Krzyżackim, t. III, Warszawa 1935, s. 75.

44 Do rozruchów wywołanych przez czeladników doszło już w 1385 roku w Toruniu i w Chełmnie, za: T. Jasiński, Rzemiosła kowalskie średniowiecznego Torunia, „Kwartalnik Historii Kultury Materialnej” 1975, R. XXIII, nr 2, s. 230.

45 Por. Historia Torunia, t. I: W czasach średniowiecza (do roku 1454), s. 229-234; Z. Zyglewski, Religijność w miastach kujawskich późnego średniowiecza, w: Ecclesia et civitas. Kościół i życie religijne w mieście średniowiecznym, s. 327-345. 
ramy oficjalnej struktury społecznej ${ }^{46}$. W obliczu faktu, iż każdy pierwiastek życia osobistego i społecznego podporządkowany był myśleniu religijnemu, jedyną formą legitymizacji władzy i instytucji okazywała się legitymizacja religijna. Toteż podziały społeczne musiały znajdować religijne potwierdzenie i sobie właściwe, różnicujące formy duchowej aktywności. Zawodowe stowarzyszenia znalazły więc przestrzeń dla swojego funkcjonowania w organizacjach o genezie religijnej. Na takim podłożu zrodziła się bardzo szybko tożsamość mieszczanina-kupca, pieniądz zajął poczesne miejsce w jego życiu, religijność sprzęgła się $\mathrm{z}$ rodzącym się kontekstem rynkowej konkurencji.

Bractwo kupieckie Najświętszej Marii Panny pojawia się już na początku XIV wieku. Kupiecka konfraternia zrzeszająca kupców-hurtowników miała swoją siedzibę, zamknięty kształt, wspólne formy spędzania czasu i świąt, wykazywała wzajemną troskę o własnych członków w trudnych sytuacjach życiowych, wykształciła odmienne formy aktywności religijnej i, rzecz najważniejsza, przychodzi moment, kiedy potrzebowała wizualnej reprezentacji swojej tożsamości - dokonała fundacji malowideł o monumentalnym charakterze (niemającym analogii w skali dekoracji podobnych kamienic), progresywnych cechach stylistycznych (poziomie realizmu i malarskości, którego nie osiągają podobnie datowane zabytki) i programie ikonograficznym godnym dekoracji świątyni bądź siedziby władzy feudalnej (bogato cytującym sceny dekoracji świątyni franciszkańskiej oraz motywy ikonograficzne eksploatowane w propagandzie władzy). Choć bractwo funkcjonowało w kamienicy, która rozwiązaniami architektonicznymi nie wyróżniała się na tle kamienic zamożnych kupców, w środku pojawiło się jedno ze szczytowych osiągnięć ściennego malarstwa gotyckiego w Toruniu. Ewidentny wydaje się wobec tego fakt, iż dekoracja malarska staje się instrumentem propagandowym obarczonym silnymi konotacjami socjologicznymi, odwołującym się do atrybutów i systemu wartości wyższych warstw społecznych (motywy dworskie, rycerskie). Ponadto zawiera ideologię i duchowe wartości legitymizujące misję Kościoła (scena Koronacji Marii jako triumf Kościoła, Walka św. Jerzego ze smokiem - symbol walki chrześcijaństwa z poganami). Ukazanie Koronacji

46 M. Bogucka, H. Samsonowicz, Miasta i mieszczaństwo, s. 236. 
w dworskiej oprawie, której geneza wywodzi się z kręgu cesarskich fundacji luksemburskiej Pragi, monarszego rytuału Pokłonu, rycerskiego etosu Walki św. Jerzego - wszystko to wnosi w przestrzeń kamienicy domu bractwa ideały i emblematy władzy zwierzchniej, podnosząc intencjonalnie aspiracje bogatych patrycjuszy zrzeszonych $\mathrm{w}$ elitarne stowarzyszenie. Jak zauważa Maria Bogucka i Henryk Samsonowicz, „nie ulega wątpliwości, że mieszczanie nie tylko w Polsce, ale w całej Europie starali się naśladować elitę władzy ówczesnego społeczeństwa" ${ }^{\text {"47 }}$. Stratyfikująca się w naturalny sposób gmina miejska w obrębie społeczeństwa stanowego i w warunkach religijnej legitymizacji władzy osiąga nową świadomość społeczną, a sztuka staje się językiem, który umożliwia jej wyrażanie. Wybór odpowiednich tematów i środków wyrazu w obrębie interesujących nas malowideł, poza funkcją jawną - kultem religijnym - miał swoje funkcje ukryte - legitymizację rodzącej się instytucji stowarzyszenia kupieckiego, podniesienie jej prestiżu, podkreślenie swojej rangi w ówczesnym kontekście społecznym. W ten oto sposób w duchu średniowiecznego uniwersalizmu specyficzna żarliwość religijna splata się nierozerwalnie z propagandą nowej świadomości mieszczańskiej, a ponadto religijne przedstawienie w świeckim wnętrzu stanowi przestrzeń mediacyjną między sacrum a profanum, stając się jeszcze jedną pośrednią formą zbliżenia ku Bogu.

Jak wynika z wyżej zaproponowanej interpretacji, wybór tematów fresków miał, poza wymiarem religijnym, aspiracyjny charakter i stanowi dowód rodzenia się nowej świadomości mieszczańskiej. Z jednej strony wybór nobilitujących tematów zawierających w sobie ideały władzy zwierzchniej i stanu rycerskiego manifestował aspiracje, z drugiej zaś dystansował warstwę bogatych kupców od niższych warstw stanu mieszczańskiego, z którego się rekrutowali.

Choć gotyckie polichromie ścienne wypełniają bardzo liczne wnętrza toruńskich kamienic mieszczańskich, rola malowideł kamienicy przy ul. Żeglarskiej 5 jest - jak usiłowałem udowodnić - wyjątkowa i bez- 
precedensowa na tle ówczesnych stosunków społecznych. Ponieważ interesująca nad dekoracja malarska wypełnia dom zebrań bogatej konfraterni kupieckiej, możliwa była rekonstrukcja przestrzeni potrzeb i aspiracji mieszczan zrzeszonych w nobilitujące stowarzyszenia religijno-zawodowe. Malowidła dekorujące kamienicę przy Żeglarskiej 5, która od przełomu XIII i XIV wieku stanowi siedzibę bractwa kupieckiego Najświętszej Marii Panny, są niezwykłym zabytkiem kultury materialnej toruńskiego patrycjatu. Przesycone mistyką i duchowością franciszkańską malowidła stanowią również dokument związków mieszczaństwa z Kościołem i wpływu, jaki odgrywał on w każdym aspekcie życia. Analogie rozwiązań ikonograficznych, systemów dekoracyjnych i znaczenie poszczególnych tematów w propagandzie władzy państwa zakonu krzyżackiego dowodzą świadomie zaprogramowanej roli malowideł $\mathrm{w}$ legitymizacji istnienia bractwa oraz roli malowideł jako instrumentu podnoszącego prestiż i znaczenie stowarzyszenia. 


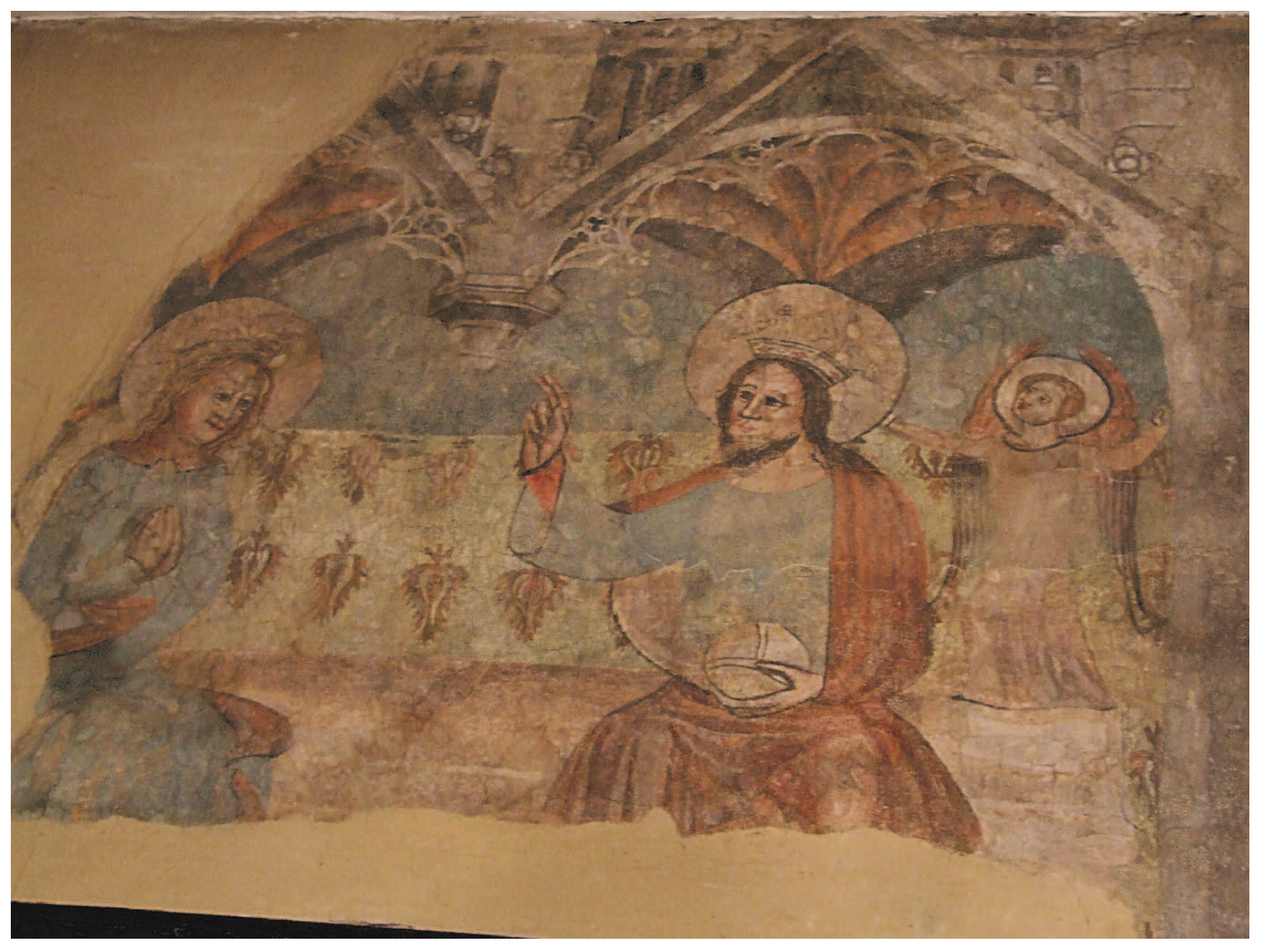

Fot.1. Koronacja Marii 


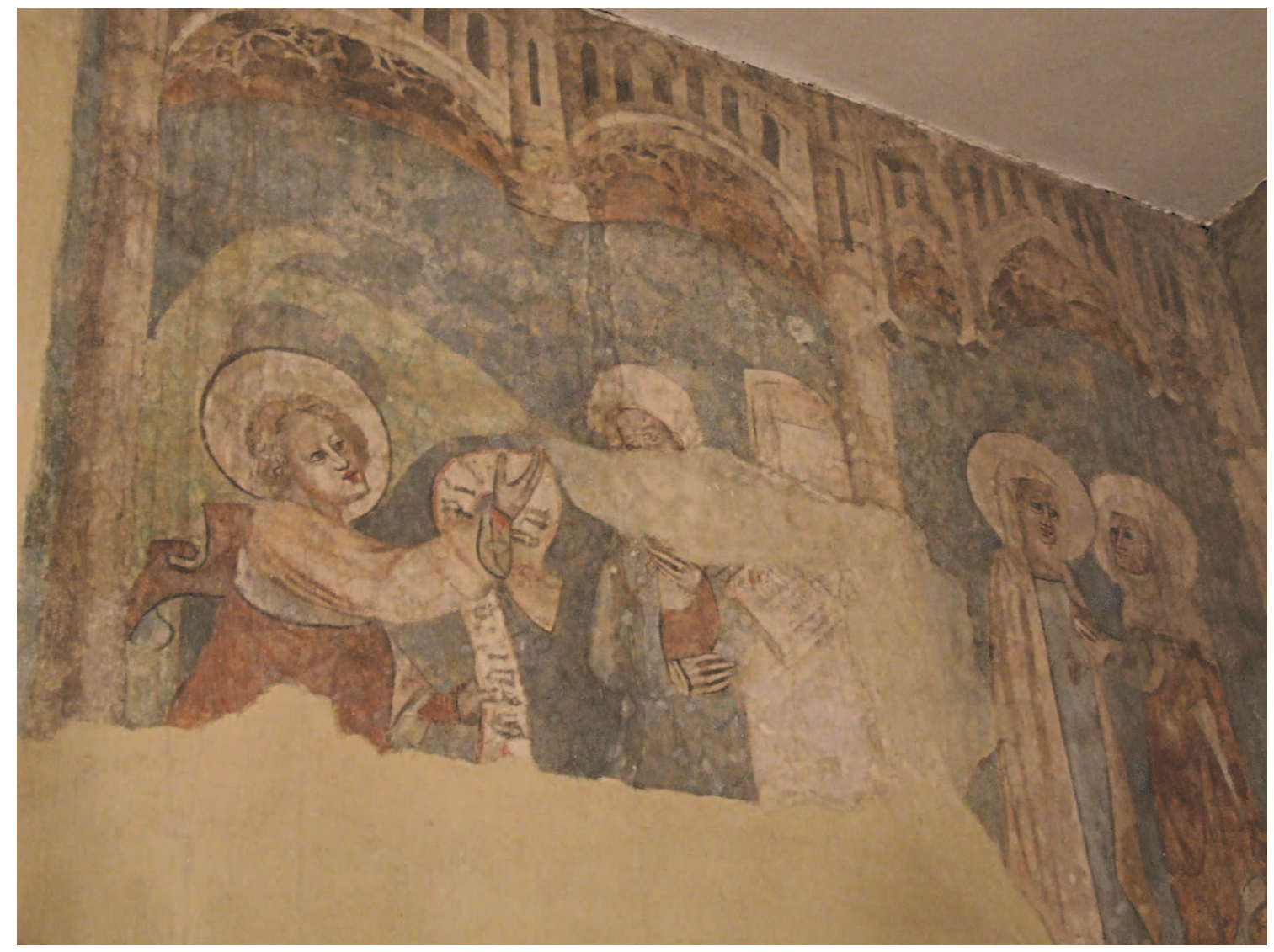

Fot. 2. Zwiastowanie i Nawiedzenie Marii 
[32]

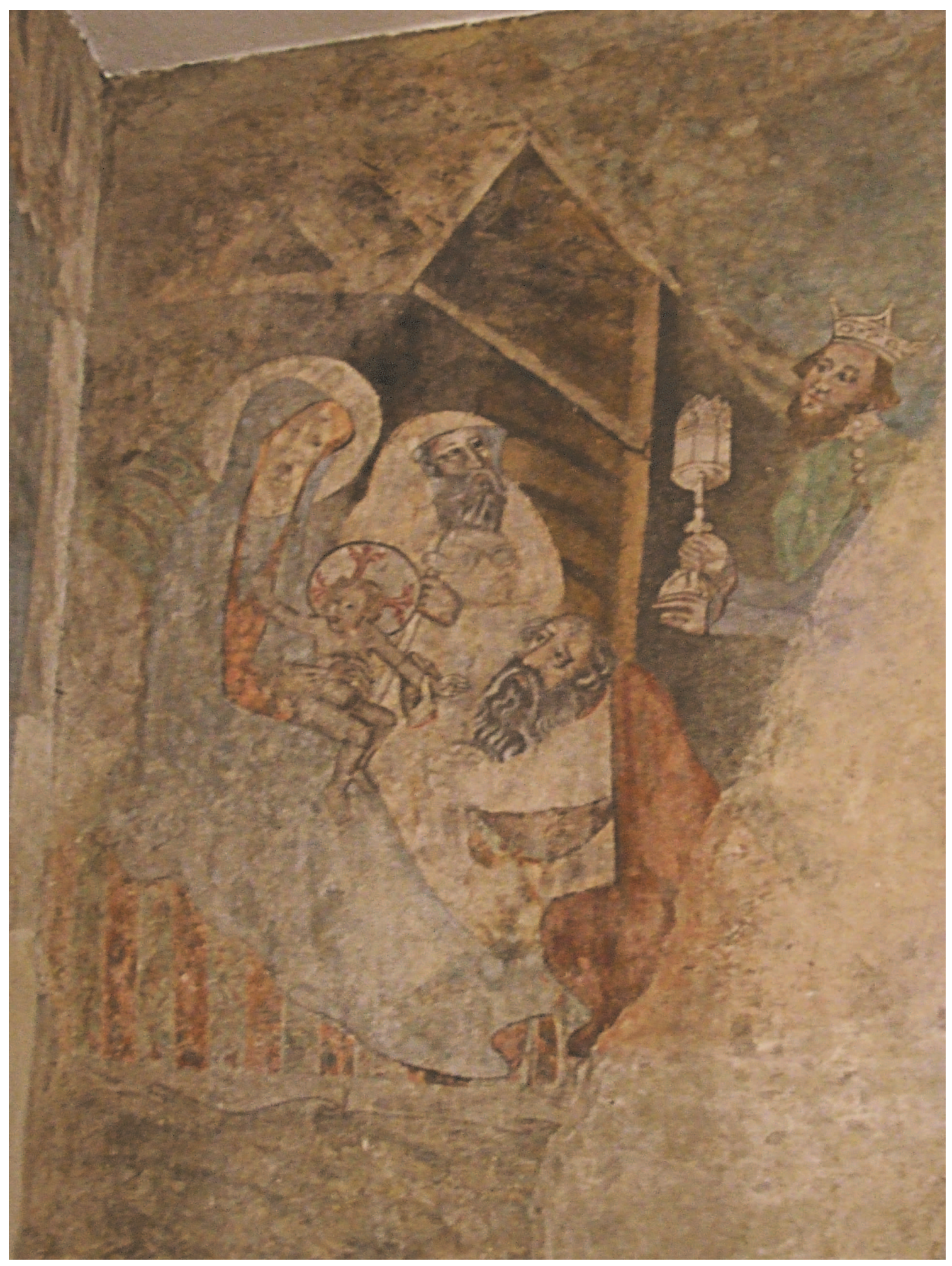

Fot. 3. Pokłon Trzech Króli 


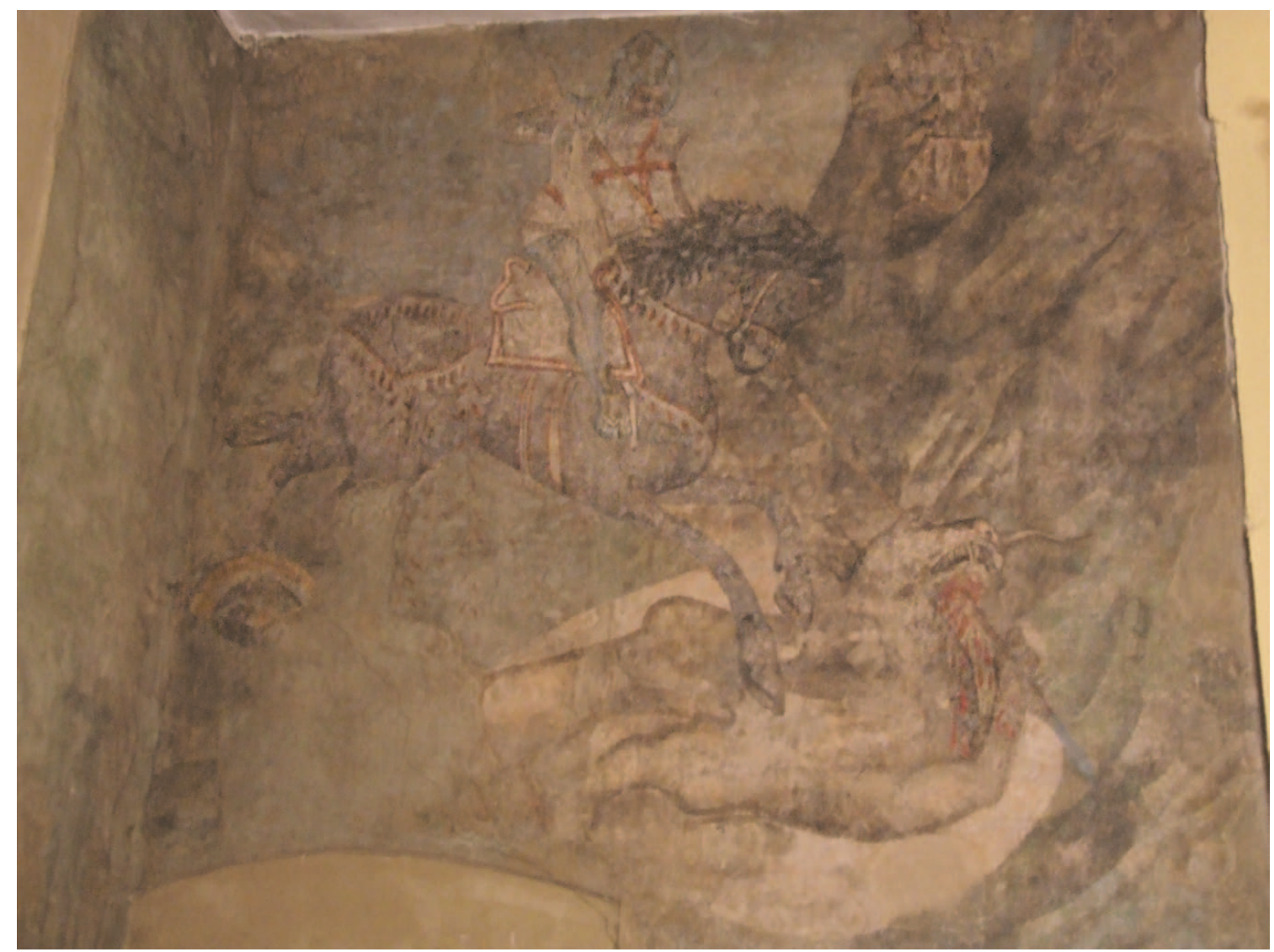

Fot. 4. Walka Świętego Jerzego ze smokiem 


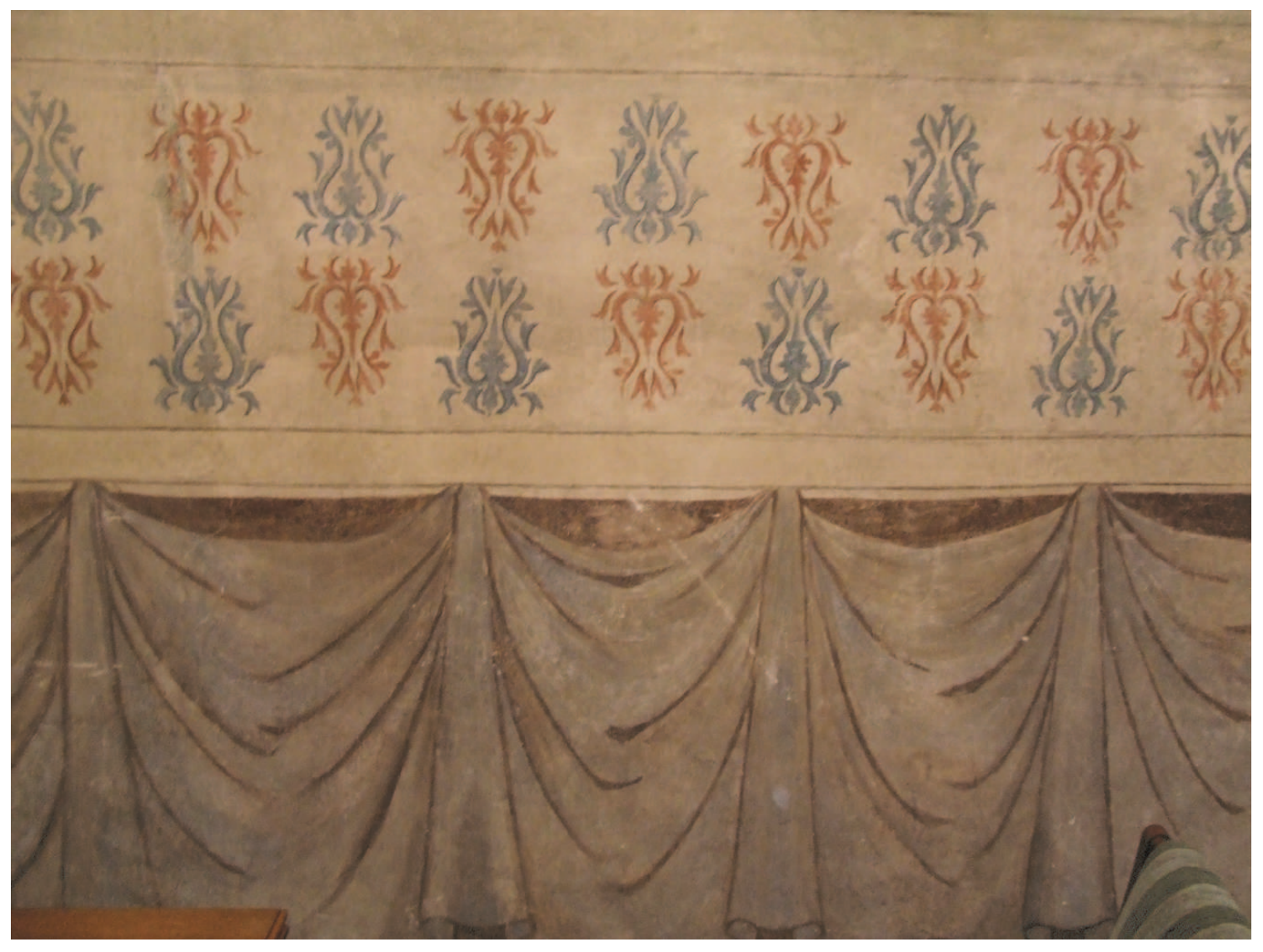

Fot. 5. Ornament szablonowy i malowana kotara poniżej fryzu figuralnego 


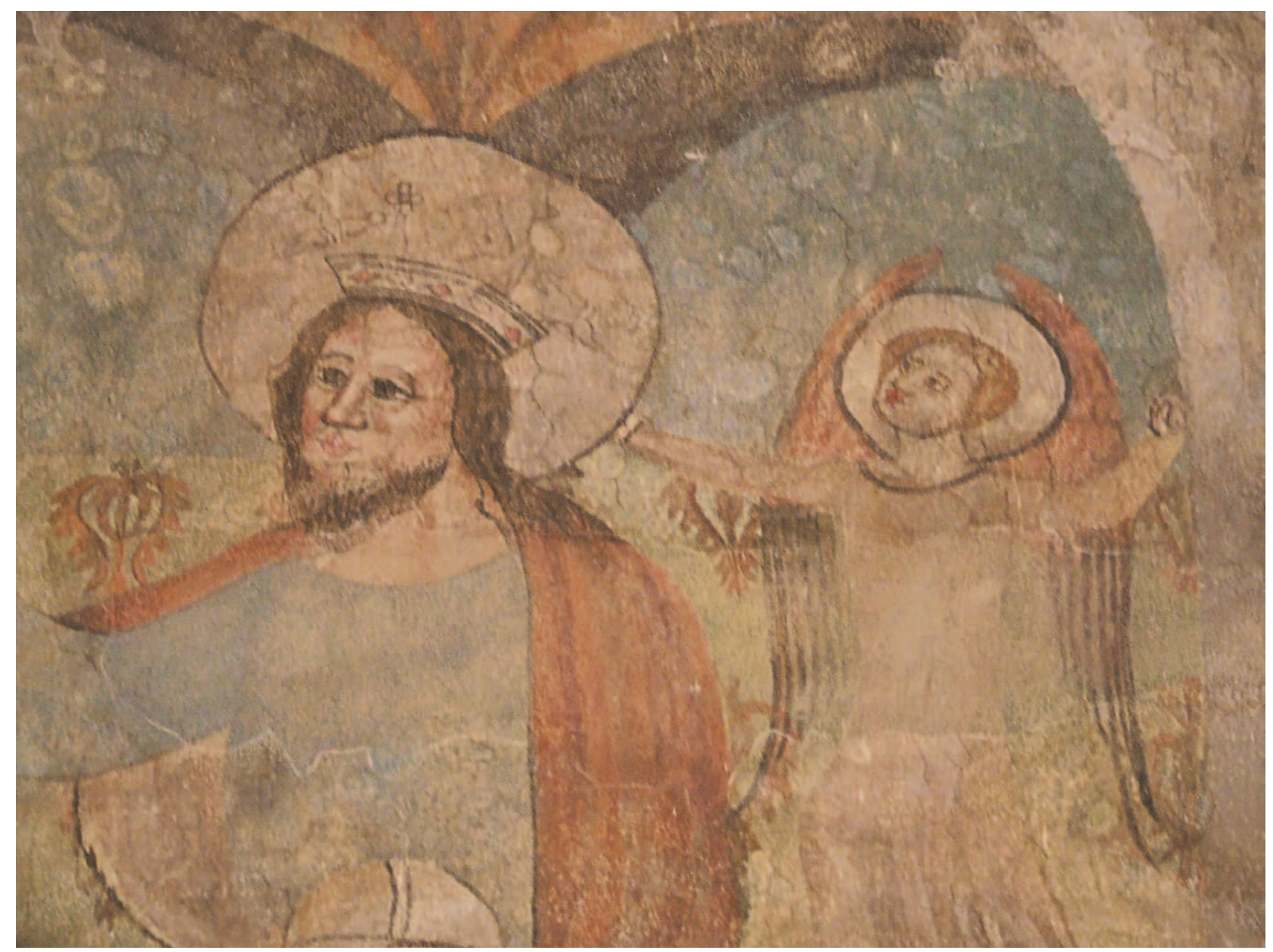

Fot. 6. Koronacja Marii, fragment 
[36]

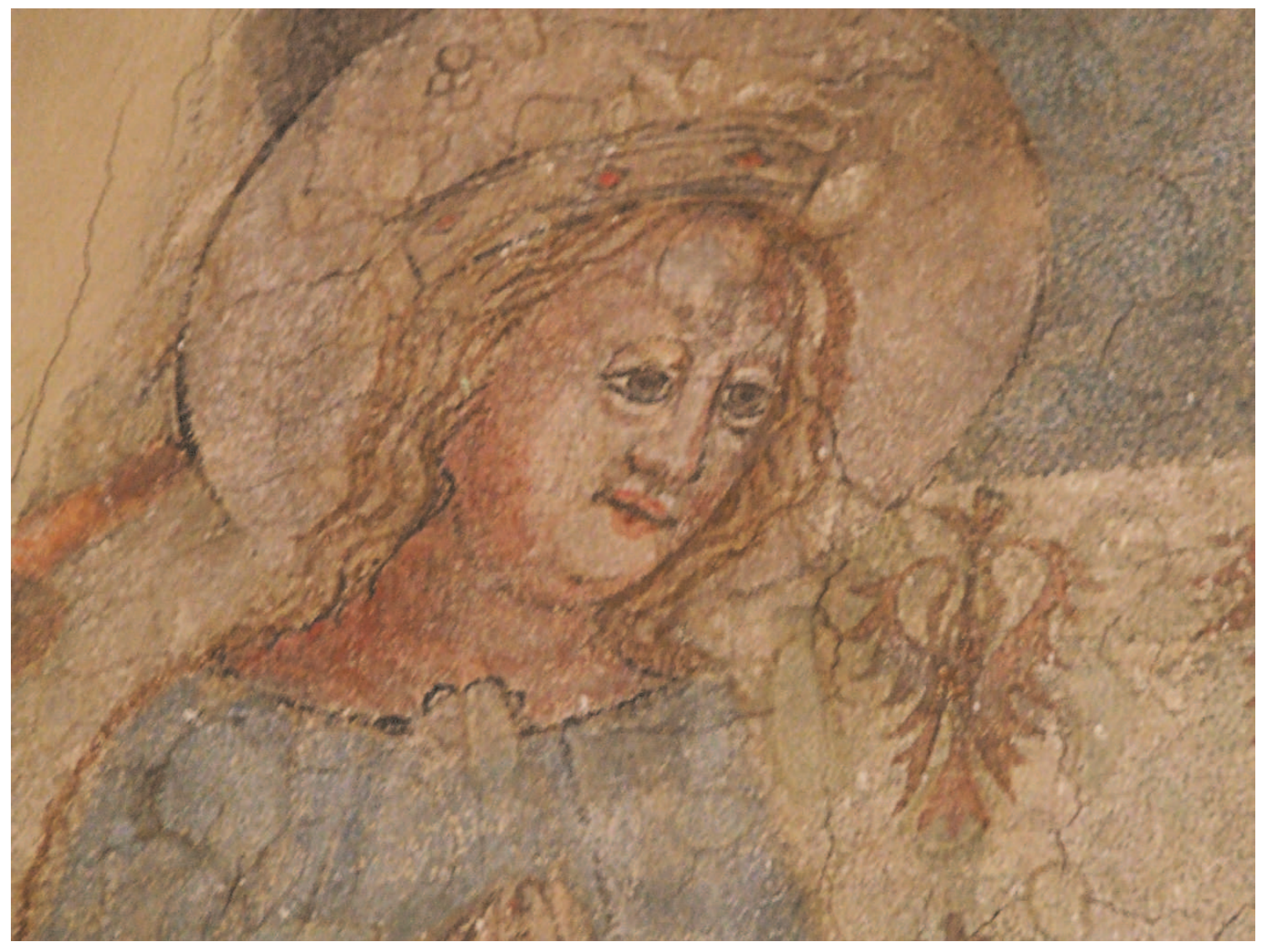

Fot. 7. Koronacja Marii, fragment 


\section{Summary}

\section{The iconography of Gothic wall-paintings in a Toruń merchant house in Żeglarska Street 5}

The subject of this article is the iconography of Gothic wall-paintings in a Toruń merchant house in Żeglarska Street 5. Although Gothic polychrome wall-paintings fill interiors of many a merchant house in the city of Torun, the role of those in Żeglarska 5 is unique and unprecedented. These frescoes decorate the walls of a meeting house of a rich merchant guild and as such give evidence of the universe of aspirations of city patricians who were part of a nobilitating religious and professional association. Since the turn of the 13th and the 14th century the building in Żeglarska 5 was the seat of the Holy Mary merchant guild and it is a rare relic of the patrician culture in the city of Torun. The frescoes are saturated with Franciscan mysticism and spirituality and are a record of relations between the city and the Church, and of the influence of this relation on every aspect of the city's life. There are clear analogies in the iconography, the decorative system and the interpretation between these frescoes and the propaganda of the feudal authority over these lands of the Teutonic Order. These analogies are a testament to the premeditated role of the frescoes in legitimising the very existence of the fraternity and building its prestige. 